\title{
The High Input of Soil Organic Matter from Dead Tree Fine Roots into the Forest Soil
}

\author{
Hans Å. Persson \\ Department of Ecology, Swedish University of Agricultural Sciences, P.O. Box 7044, 75007 Uppsala, Sweden \\ Correspondence should be addressed to Hans Å. Persson, hans.persson@ekol.slu.se
}

Received 7 December 2011; Revised 2 February 2012; Accepted 2 February 2012

Academic Editor: Jingxin Wang

Copyright (๖ 2012 Hans Å. Persson. This is an open access article distributed under the Creative Commons Attribution License, which permits unrestricted use, distribution, and reproduction in any medium, provided the original work is properly cited.

The spatial and temporal dynamics of tree fine roots were investigated in six boreal forests types in Eastern Sweden, close to the Swedish Forsmark and Laxemar nuclear power plants. Four dry and two wet forest types were included in the study. The amount of live and dead fine roots in terms of dry weight was estimated in soil cores. The live/dead ratios of fine roots $(<1 \mathrm{~mm}$ in diameter) decreased with depth; very low ratios were observed in two wet forest sites. The proportions of dead fine roots to the total amounts of fine roots in the mineral soil horizons of those wet sites were 63 and $86 \%$. The corresponding proportions in the mineral soil in dry forest sites were 45 and $45 \%$ and 49 and $48 \%$ at Forsmark and Laxemar, respectively. Sequential soil core sampling demonstrated a high variation in live and dead amounts of fine roots during the growth period. A high accumulation of carbon from dead tree fine root was found in all six forest types, in particular in the wet forest sites, but also in deeper soil horizons. Consequently, substantial amounts of organic matter from dead fine roots are continuously accumulated in the soil in boreal forests.

\section{Introduction}

Tree fine roots of forest trees are for their function forced to penetrate dry soil volumes often against mechanical resistance in densely packed soil layers. In spite of those difficulties, tree root systems explore the uppermost parts of the soil profile with a network of growing root tips. For an example, the root system of a 13-year-old Scots pine (Pinus sylvestris) reached an area of about $5 \mathrm{~m}$ from the tree stem and expanded about $0.4 \mathrm{~m} \mathrm{yr}^{-1}[1,2]$. The high tree density in this forest stand $\left(1095 \mathrm{ha}^{-1}\right)$ made it clear that the uppermost parts of the soil profile must have been completely interwoven by tree fine roots.

The lateral roots in a nearby 120 -year-old Scots pine stand (tree density $=393 \mathrm{ha}^{-1}$ ) reached $15-20 \mathrm{~m}$ from the tree trunks [3]. The root system of those mature Scots pine trees had expanded about $0.1 \mathrm{~m} \mathrm{yr}^{-1}$ during the 120 year period leaving an area of about $300 \mathrm{~m}^{-2}$ penetrated by tree roots. The wide-spread network of fine roots on the structural roots increases the total surface area and length of the root system [4].

The white coloured area of the root tips behind the region of cell elongation is most active in the uptake processes $[5,6]$.
This absorption zone is often covered by mycorrhizal fungi or root hairs [7]. The seasonal change in the number of root tips seems to be very well correlated with the changes in the amount and length and surface area of living fine roots [8]. Fine roots are short lived in their effectiveness; death and decay of dead fine roots often take place within a few weeks.

The energy cost of forming and maintaining the fine root system of a single tree is very high [9-13].The amount of carbon allocated to the root systems is substantial $[2,8,9$, $12,14-17]$. The starch content in living fine roots $(<1 \mathrm{~mm}$ in diameter) may reach as much as $30 \%$ of the dry weight [18]. Live fine root ramifications are constantly replaced and a substantial amount of dead fine-root tissues are formed.

Fine root production and litter formation of fine roots are important components of nutrient and carbon cycles in forest ecosystems $[2,8,12,14,16,17,19-25]$. Calculating carbon allocation to tree fine roots and turnover time is therefore essential in order to understand the patterns of carbon cycling in forest ecosystems.

The most commonly used methods of estimating fineroot production in forest ecosystems involve the measurements of live and dead amounts of fine roots in terms of dry weight from sequential soil cores. The contribution of 
different diameter classes to root biomass and turnover rate may vary $[4,15]$. The most substantial turnover rate is to be found in fine roots. Some fine roots are transferred to longliving large-diameter roots $[13,15]$.

The live/dead ratio of fine roots is a valuable vitality criterion in the soil profile [26]. Persson and Ahlström [27] used the live/dead ratio of fine roots to quantify changes in the "vitality" of fine roots in nitrogen manipulated Norway spruce catchment areas. The fluctuations in the amount of live and dead fine roots during the growth period in these forest areas suggested that climatic alterations were the most important underlying sources of variation. Soil temperature and soil water conditions seem to be the most important factors influencing fine-root growth. The most substantial decomposition takes place in the upper soil layers where high temperature, supplies of air, water, and food allow microorganisms to thrive $[28,29]$.

The effects of anoxic conditions on the spatial and temporal distribution on the tree fine roots have recently been identified $[15,26,30]$. The live/dead ratio of fine roots may be reduced in water saturated forest soils as a result of oxygen deficiency, a low rate of decomposition, and a substantial accumulation of decomposing organic matter from dead fine roots [31-33].

The boreal forests are in many ways able to keep plant remains from decomposing, thus preventing the release of carbon into the air. Most carbon is accumulated in poorly and very poorly drained soils. A high share of forested wetlands is to be found in the boreal forest region [34-36]. In boreal forests tree fine roots are exposed to large seasonal variations of soil moisture, nutrient availability, and soil temperature [37, 38]. In water-saturated forest stands the accumulation of dead fine roots is expected to be very high.

We hypothesized that soil water saturation plays an important role in regulating the amount of deposed organic matter from dead fine roots. A low live/dead ratio of fine roots is expected in water-saturated forest stands as a result of the high accumulation of dead root tissues. Soil carbon from dead tree roots plays a key role in the global carbon cycle and is an important component in climate models. Humans have, and will likely continue to have, significant impacts on the size of this pool by forest management practices forest such as forest harvesting, clear-cutting, ploughing, and drainage.

\section{Material and Methods}

Investigations were carried out in six different forest types in areas surrounding two Swedish nuclear power plants at Forsmark and Laxemar $[15,26]$. The forest sites at Forsmark were of coniferous Calluna-Empetrum type, coniferous fern type, and Alnus swamp of herb type [39]. A distinct hummock and hollow microtopography was developed at the Alnus forest of swamp herb type at Forsmark.

The sites at Laxemar were of herb rich oak forest type, coniferous Vaccinium myrtillus type, and Alnus shore forest type. The soil type varied between leptosol/regosols) gleysols at Forsmark and histosols/gleysol at Laxemar (see Table 1). Stone/boulder volumetric content (\%) and soil moisture conditions differed considerably between the different sites [26].

The tree density (the number of trees $\mathrm{ha}^{-1}$ ) was 1340 , 780, and 3340 at the Forsmark and 200, 400, and 1600 at the Laxemar sites, respectively. The mean tree height was 16.3, 19.8, and $18.5 \mathrm{~m}$ at the Forsmark sites and 17.1, 21.0, and $11.6 \mathrm{~m}$ at the Laxemar sites, respectively. The mean tree height of the trees was $16.3,19.8$ and $18.5 \mathrm{~m}$ at the Forsmark and $17.1,21.0$, and $11.6 \mathrm{~m}$ at the Laxemar sites, respectively (Table 1$)$. The basal area $\left(\mathrm{m}^{2} / \mathrm{ha}\right)$ of the trees was $22.5,27.0$, and 17.9 at the Forsmark sites and 15.0, 15.5, and 17.5 at the Laxemar sites, respectively. The specific basal area was occupied by different tree species.

The Alnus swamp forest site at Forsmark consisted besides Alnus glutinosa (Table 1; basal area $=7.3 \mathrm{~m}^{2} \mathrm{ha}^{-1}$ ) of Betula verrucosa, Picea abies, and Pinus sylvestris (total basal area $=10.3 \mathrm{~m}^{2} \mathrm{ha}^{-1}$ ). The Alnus shore forest at Laxemar consisted of Alnus glutinosa (basal area $=17.5 \mathrm{~m}^{2} \mathrm{ha}^{-1}$ ). The coniferous Calluna-Empetrum site, the coniferous fern site at Forsmark and the coniferous Vaccinium site at Laxemar were dominated by Picea abies (basal area $=22.5$ and $15.5 \mathrm{~m}^{2} \mathrm{ha}^{-1}$ ) and the herb rich oak forest at Laxemar by Quercus robur (basal area $=15.0 \mathrm{~m}^{2} \mathrm{ha}^{-1}$ ). The average thickness of the humus layer was $15.3,5.2$, and $15.3 \mathrm{~cm}$ at the Forsmark sites and $11.5,5.5$, and $5.3 \mathrm{~cm}$ at the Laxemar sites.

In total 32 soil cores were taken in each forest site from the four corners of a quadrate covering $200 \mathrm{~m}^{2}, 8$ taken randomly in each corner (north, east, south, and west) [15, 26]. Each soil sample was taken as deep as possible, namely, to a depth where stones and larger blocks prevented further penetration by the soil corer.

Soil cores were sampled in the middle of October 2004 for the Forsmark sites and in the end of April 2005 for the Laxemar sites. During the winter months the upper part of the soil profile was deep frozen, and only limited growth of the fine roots could take place. The soil cores were randomly distributed within the hummock and hollow microtopography pattern at the Alnus forest of swamp herb type at Forsmark. Half of the soil core samples were taken in the hummocks and the other half in the hollows. In all other forest sites no stratification was applied.

Additional sequential soil core sampling was carried at the coniferous fern forest type at Forsmark on in total 4 sampling occasions [26]. Besides the first sampling in the middle of October in 2004, samplings were carried out in the middle of April, in the beginning of August and in the end of October in 2005 [15]. The depth distribution of fine roots was measured, at intervals of 0-2.5 (H1), 2.5-5 (H2), and 5$10 \mathrm{~cm}(\mathrm{H} 3)$ of the LFH horizon and in $10 \mathrm{~cm}$ segments (M1M3) for the mineral soil profile down to $30 \mathrm{~cm}$.

A cylindrical steel corer, with an inner diameter of $4.5 \mathrm{~cm}$, was used for soil core sampling. In total 32 soil cores were taken, each soil core sample was taken to a depth where stones and larger blocks prevented further penetration by the soil corer. Only few root fragments were found in the deepest soil layer. The uppermost $0-2.5 \mathrm{~cm}$ layer consisted of humus in all investigated sites.

The soil samples were transferred into plastic bags and transported to our laboratory and stored in a cold storage 
Table 1: Site and stand characteristics at Forsmark and Laxemar. Picea abies $=$ P. a., Pinus sylvestris $=$ P. s., Betula verrucosa $=$ B. v., Alnus glutinosa $=$ A. g., Quercus robur $=$ Q. $r$.

\begin{tabular}{|c|c|c|c|c|c|c|}
\hline Stand characteristics & $\begin{array}{c}\text { Coniferous, } \\
\text { Calluna empetrum }\end{array}$ & Coniferous fern & $\begin{array}{c}\text { Alnus } \\
\text { swamp herb }\end{array}$ & $\begin{array}{l}\text { Herb rich oak } \\
\quad \text { forest }\end{array}$ & $\begin{array}{l}\text { Coniferous } \\
\text { Vaccinium } \\
\text { myrtillus }\end{array}$ & $\begin{array}{c}\text { Alnus } \\
\text { shore forest }\end{array}$ \\
\hline Soil moisture class ${ }^{1}$ & Fresh & Fresh/moist & Moist & Fresh & Fresh & Moist \\
\hline Soil type ${ }^{1}$ & Leptosol & Regosol/Gleysol & Gleysol & Histosol/Gleysol & Histosol & Histosol \\
\hline Tree age & $59-60$ & $80-88$ & $85-95$ & 112 & 55 & 34 \\
\hline Number of trees /ha & 1340 & 780 & 3340 & 200 & 400 & 1600 \\
\hline Tree height (m) & 16.3 & 19.8 & 18.5 & 17.1 & 21.0 & 11.6 \\
\hline $\begin{array}{l}\text { Diameter at breast } \\
\text { height (dbh in } \mathrm{m})\end{array}$ & 0.21 & 0.26 (P. a.) & $0.31(P . a)$ & 0.36 & 0.32 & 0.14 \\
\hline Basal area $\left(\mathrm{m}^{2} / \mathrm{ha}\right)$ & 22.5 (P. a.) & $\begin{array}{l}20.5(\text { P. a. }) \\
6.5(\text { B. v. })\end{array}$ & $\begin{array}{l}5.3 \text { (B. v.) } \\
7.3 \text { (A. g.) } \\
3.0 \text { (P. a.) } \\
2.3 \text { (P. s.) }\end{array}$ & $15.0(Q . r)$. & $15.5($ (. a. $)$ & 17.5 (A.g.) \\
\hline
\end{tabular}

${ }^{1}[40,41]$.

at $-4^{\circ} \mathrm{C}$; a temperature that did not damage the live tissue and caused no change in ion concentrations [42]. The roots were sorted out from the soil cores immediately after thawing. In order to distinguish live roots from dead roots distinct morphological characteristics were used [43].

Live fine roots $(<1 \mathrm{~mm}$ in diameter $)$ were defined as roots with a varying degree of brownish/suberized tissues, often well branched, with the main part of the root tips light and turgid or changed into mycorrhizal root tips $[43,44]$. In cases when there was a difficulty to judge if a root fragment was live or dead, it was cut lengthwise with a sharp dissection knife and the judgement was based on the colour between cortex and periderm. The stele of live roots was white to slightly brown and elastic. In roots considered as dead, the stele was brownish and easily broken, and the elasticity was reduced. Dead root fragments with a length $<1 \mathrm{~cm}$ were regarded as soil organic matter. The dry weight was estimated for all root fractions after drying in an oven at $65^{\circ} \mathrm{C}$ to constant dry weight (at least for 24 hours).

The fine-root production and turnover rates were calculated from significant (Student's $t$-test) increments of live, dead, and live + dead fine roots at the coniferous fern forest at Forsmark. Comprehensive descriptions of calculation methods used are to be found in [8]. By turnover rate, in this context, was meant the annual fluxes in the live, dead, or in the live + dead fine-root compartment. Root turnover rate $\left(\mathrm{yr}^{-1}\right)$ was calculated from the annual increments in live, dead and, live + dead fine roots divided by the average amounts in those categories during the year of sampling.

From these calculations only minimum estimates of turnover rate can be obtained since the sampling frequency (only four sampling occasions) covered only some of the major fluctuations, but certainly not all increases. The risk for overestimation due to the random variations in the means is low with a low number of sampling occasions and a high number of samples on each sampling occasion [8].

\section{Results}

A substantial variation with depth in the total amount of live and dead tree fine roots was observed at the different forest sites (Figure 1). High amounts of dead fine roots were indicated in the mineral soil horizons. The proportion of dead fine roots varied at all sites and in all horizons from 6 to $88 \%$ (Table 2 ). The highest proportions of dead fine roots were found in the two Alnus forest sites at Forsmark and Laxemar, which were both classified as "moist," with a high topographic wetness index (cf. Table 1). The live/dead ratio of fine roots $(<1 \mathrm{~mm}$ in diameter) varied in all sites from 14.1 in the uppermost $2.5 \mathrm{~cm}$ of the humus layer to 0.2 in the deepest parts of the mineral soil horizon (Table 2). The live/dead ratio is calculated only for soil cores with both live and dead fine roots.

Low amounts of live fine roots were found in the uppermost $2.5 \mathrm{~cm}$ of soil of the moist Alnus shore forest at Laxenar compared with the same soil segments at other forest sites (Figure 1 and Table 2 ). The total amounts of fine roots were very low at the latter site and substantial amounts of dead fine roots were found in the total soil profile. At the moist Alnus swamp forest at Forsmark, a more substantial proportion of live fine roots were observed in the total soil profile, resulting in a comparatively high live/dead ratio, in particular in the humus layers (Table 2 ).

The rooting density $\left(\mathrm{g} \mathrm{dm}^{-3}\right)$ was low at all sites in the mineral soil horizons compared with in the humus layers except for in the coniferous fern forest at Forsmark (Figure 1). A low live/dead ratio of fine roots was found in the deepest soil horizons, where the rooting density was very low (Table 2). Extremely low rooting density was observed in the mineral soil horizons at the Alnus swamp forest at Forsmark, at the herb rich oak forest at Laxemar and at the Alnus shore forest. The soil corer was driven in all sites to depths in the mineral soil horizon (at least $2 \mathrm{dm}$ ) where only 

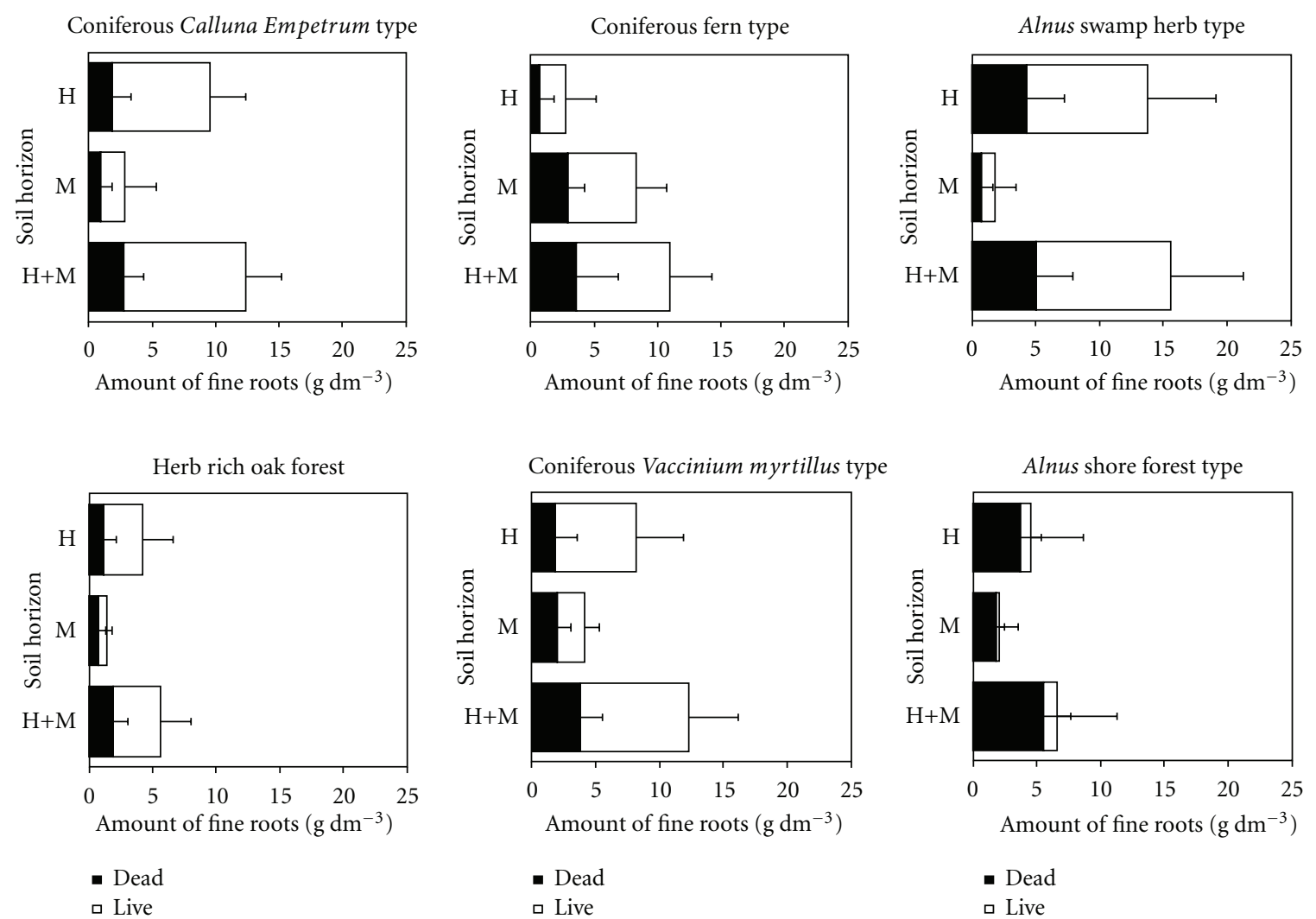

Figure 1: The amount of live and dead tree fine roots $\left(\mathrm{g} \mathrm{dm}^{-3} ;<1 \mathrm{~mm}\right.$ in diameter) in the humus layer $(\mathrm{H})$ and in the mineral soil horizon (M) compared with in the total soil profile $(\mathrm{H}+\mathrm{M})$ at different Swedish forest sites.

limited amounts of live or dead fine-root fragments were observed (Table 2).

The mean amount of live tree fine roots in the humus layer in relation to the total amount of live + dead fine roots in the soil profile was 48,7 , and $48 \%$ for the three Forsmark sites and 35, 25, and 6\% for the three Laxemar sites, respectively (Figure 1, Table 2). The related amount of dead fine roots in the humus layer was 13,2 , and $30 \%$ for the Forsmark and 13,2, and 28\% for the Laxemar sites, respectively. Proportionally more live than dead fine roots were observed at all sites in the humus compared with in the mineral soil horizon, except for at the Alnus shore forest site at Laxemar (Figures 1 and 2). The density estimates (Figure $1 ; \mathrm{g} \mathrm{dm}^{-3}$ ) give a more correct picture of the extensive distribution of live fine roots in the humus layer than simply the distribution per unit area in different soil layers (Figure 2 and Table 2; $\mathrm{g} \mathrm{m}^{-2}$ ).

The proportion of dead fine roots $(<1 \mathrm{~mm}$ in diameter) of the total amount of fine roots in the humus layer (Table 2) was high in both moist Alnus forest at Forsmark and Laxemar sites (38 and 82\%, resp.). A distinct hummock and hollow microtopography was developed at the Alnus forest of swamp herb type at Forsmark and tree fine roots were more frequently found in the uppermost aerated parts of hummocks. The tree layer consisted of a mixture of Betula verrucosa, Picea abies, and Pinus sylvestris (Table 1). At the water-saturated Alnus glutinosa shore forest at Laxemar, no

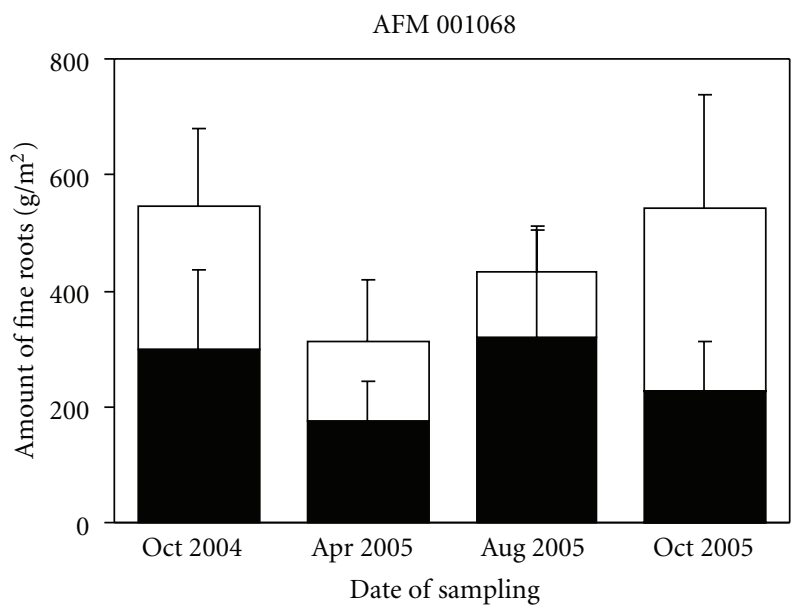

FIgUre 2: The amount of live (unfilled bar) and dead (black bar) fine roots $(<1 \mathrm{~mm}$ in diameter) on the four sampling occasions in the coniferous fern site at Forsmark during 2004-2005. Mean values \pm SD.

hummocks were found and anaerobic conditions reached even the uppermost parts of the soil horizon.

Substantial variations in live and dead amounts of fine roots and live/dead ratios were observed in the coniferous fern site at Forsmark during the sampling period confirming 
TABLE 2: The distribution of live and dead amounts of tree fine roots ( $<1 \mathrm{~mm}$ in diameter), live/dead ratios, and dead (\%) at different depths ( $\mathrm{H}$ = humus; $\mathrm{M}=$ mineral soil) at the forest sites: Forsmark-1 (Coniferous, Calluna Empetrum type), Forsmark-2 (Coniferous fern type) and Forsmark-3 (Alnus swamp herb type) and Laxemar-1 (herb-rich oak forest), Laxemar-2 (Coniferous Vaccinium myrtillus type), and Laxemar-3 (Alnus shore forest type) forest sites. The live/dead ratio is calculated from the mean amounts of live and dead tree fine roots. Estimates are given as mean values $\pm \mathrm{SD}(n=31-32)$.

\begin{tabular}{|c|c|c|c|c|c|}
\hline \multirow{2}{*}{ Site } & \multirow{2}{*}{ Horizon } & \multicolumn{4}{|c|}{ Tree roots $\left(\mathrm{g} \mathrm{m}^{-2}\right)$} \\
\hline & & Live & Dead & Live/dead ratio & Dead (\%) \\
\hline \multirow[t]{7}{*}{ Forsmark-1 } & H $0-2.5$ & $48 \pm 42$ & $3 \pm 9$ & 13.3 & 6 \\
\hline & H $2.5-5$ & $64 \pm 29$ & $15 \pm 22$ & 4.2 & 19 \\
\hline & H 5-10 & $60 \pm 63$ & $21 \pm 25$ & 2.9 & 26 \\
\hline & H 10-15 & $9 \pm 20$ & $9 \pm 21$ & 0.9 & 50 \\
\hline & H 15-20 & $2 \pm 9$ & $2 \pm 12$ & 1.0 & 50 \\
\hline & M 0-10 & $71 \pm 96$ & $58 \pm 63$ & 1.2 & 45 \\
\hline & M 10-20 & $13 \pm 59$ & $10 \pm 21$ & 1.3 & 43 \\
\hline \multirow[t]{6}{*}{ Forsmark-2 } & Н $0-2.5$ & $30 \pm 35$ & $4 \pm 5$ & 7.5 & 12 \\
\hline & Н 2.5-5 & $4 \pm 12$ & $4 \pm 11$ & 1.1 & 50 \\
\hline & H 5-10 & $2 \pm 6$ & $3 \pm 10$ & 0.6 & 60 \\
\hline & M 0-10 & $228 \pm 138$ & $136 \pm 70$ & 1.7 & 37 \\
\hline & M 10-20 & $51 \pm 67$ & $73 \pm 60$ & 0.7 & 59 \\
\hline & M 20-30 & $2 \pm 8$ & $5 \pm 15$ & 0.4 & 71 \\
\hline \multirow[t]{8}{*}{ Forsmark-3 } & H $0-2.5$ & $56 \pm 58$ & $11 \pm 11$ & 5.1 & 16 \\
\hline & Н 2.5-5 & $46 \pm 36$ & $23 \pm 21$ & 2.0 & 33 \\
\hline & H 5-10 & $55 \pm 52$ & $51 \pm 40$ & 1.1 & 48 \\
\hline & H $10-15$ & $28 \pm 35$ & $25 \pm 33$ & 1.1 & 47 \\
\hline & H 15-20 & $13 \pm 30$ & $9 \pm 16$ & 1.5 & 41 \\
\hline & H 20-25 & $3 \pm 9$ & $6 \pm 22$ & 0.5 & 67 \\
\hline & M 0-10 & $29 \pm 73$ & $45 \pm 55$ & 0.6 & 61 \\
\hline & M 10-20 & $6 \pm 11$ & $14 \pm 21$ & 0.4 & 70 \\
\hline \multirow[t]{5}{*}{ Laxemar-1 } & Н $0-2.5$ & $24 \pm 28$ & $7 \pm 10$ & 3.4 & 23 \\
\hline & Н 2.5-5 & $34 \pm 37$ & $15 \pm 16$ & 2.3 & 31 \\
\hline & H 5-10 & $21 \pm 28$ & $8 \pm 12$ & 2.6 & 28 \\
\hline & M 0-10 & $57 \pm 42$ & $48 \pm 34$ & 1.2 & 46 \\
\hline & M 10-20 & $3 \pm 7$ & $9 \pm 23$ & 0.3 & 82 \\
\hline \multirow[t]{7}{*}{ Laxemar-2 } & H 0-2.5 & $102 \pm 61$ & $18 \pm 23$ & 5.6 & 15 \\
\hline & Н 2.5-5 & $48 \pm 52$ & $17 \pm 21$ & 3.0 & 26 \\
\hline & H 5-10 & $10 \pm 29$ & $11 \pm 30$ & 0.9 & 52 \\
\hline & M 0-10 & $132 \pm 69$ & $71 \pm 48$ & 1.8 & 35 \\
\hline & M 10-20 & $51 \pm 49$ & $71 \pm 37$ & 0.7 & 58 \\
\hline & M 20-30 & $25 \pm 49$ & $31 \pm 32$ & 0.8 & 38 \\
\hline & M 30-40 & $4 \pm 10$ & $26 \pm 34$ & 0.2 & 87 \\
\hline \multirow[t]{7}{*}{ Laxemar-3 } & Н $0-2.5$ & $14 \pm 17$ & $47 \pm 79$ & 0.3 & 77 \\
\hline & Н 2.5-5 & $5 \pm 9$ & $38 \pm 57$ & 0.1 & 88 \\
\hline & H 5-10 & $1 \pm 4$ & $7 \pm 19$ & 0.1 & 33 \\
\hline & M 0-10 & $17 \pm 25$ & $115 \pm 104$ & 0.1 & 87 \\
\hline & M 10-20 & $7 \pm 16$ & $35 \pm 40$ & 0.2 & 85 \\
\hline & M 20-30 & $3 \pm 8$ & $21 \pm 33$ & 0.1 & 84 \\
\hline & M 30-40 & $2 \pm 8$ & $10 \pm 14$ & 0.2 & 83 \\
\hline
\end{tabular}


TABLE 3: The amount of live, dead, and live + dead fine roots $(<1 \mathrm{~mm}$ in diameter $)$ and differences on different sampling occasions, annual means, $\Sigma$ annual increases of fine roots and turnover rate of live, dead, and live + dead fine roots at a fresh/moist coniferous fern forest site at Forsmark.

\begin{tabular}{lccc}
\hline Sampling number & Live & Dead & Live + dead \\
\hline$(1)$ & $317 \pm 196$ & $226 \pm 88^{\mathrm{a}}$ & $543 \pm 205$ \\
$(2)$ & $113 \pm 79^{\mathrm{a}}$ & $321 \pm 184^{\mathrm{a}}$ & $434 \pm 212$ \\
$(3)$ & $150 \pm 112$ & $180 \pm 62^{\mathrm{b}}$ & $330 \pm 136^{\mathrm{a}}$ \\
$(4)$ & $248 \pm 134^{\mathrm{a}}$ & $299 \pm 136^{\mathrm{b}}$ & $546 \pm 212^{\mathrm{a}}$ \\
\hline Annual means & 207 & 257 & 463 \\
\hline$\sum$ Annual increases & 135 & 214 & 216 \\
\hline Turnover rate & 0.7 & 0.8 & 0.5 \\
\hline
\end{tabular}

Sampling took place on 4 sampling occasions: October 20th, 2004 (1), April 18th, 2005 (2), August 2nd, 2005 (3), and October 28th, 2005 (4). Estimates are given as mean values $\pm \mathrm{SD}(n=32)$. Significant increases are marked by ${ }^{\mathrm{a}}$ and $^{\mathrm{b}}$. Differences are significant at $P=0.05$ (Student's $t$-test).

a high turnover rate in live, dead, and live + dead fine roots (Table 3). Low amounts of dead fine roots were found at the remaining sites at Forsmark and Laxemar, in particular in the upper well-oxidized parts of the humus layer. Although, no sequential soil coring was carried out at the two moist Alnus forest sites, high turnover rates of live fine roots must explain the high accumulation rate of dead fine roots. Thus, anoxia may play an important role in regulating the rate of organic matter accumulation in forest soils.

\section{Discussion}

The methods used of estimating fine-root production and mortality should involve the measurements of live and dead dry weight of fine roots from soil cores in undisturbed soil horizons. The often reported discrepancy in the estimates of root litter formation in data from sequential coring may partly be due to imprecise definition of vitality and size classes of the fine roots. In our case distinct morphological characteristics were used in order to separate live and dead fine roots $[8,43]$. In roots considered as dead, the stele was brownish and easily broken, and the elasticity was reduced [43]. Dark coloured tissues are frequently found in live fine roots and the colour in itself is not a reliable criterion of vitality. Depending on the pattern of cell death, several root functions can cease even before cell dies [45].

Substantial variations in live and dead fine roots and live/dead ratios usually occur in tree stands confirming our calculations of turnover rates $[4,17,23,27,39,46-50]$. The dead amounts of fine roots normally do not persist for long in well-oxidized conditions, decay or complete disappearance is accomplished in a few days only $[8,49,51]$. Under anoxic conditions there is an accumulation of dead fine roots, since the decomposition will be reduced $[33,52$, 53]. Under long-term anoxic conditions, for example, the case, at the Alnus swamp forest of herb type at Forsmark and at the Alnus shore forest at Laxemar, an accumulation of dead fine roots was observed.

Fine roots respond quickly to environmental changes and are rapidly penetrating favourable the soil horizons.
We know that fine roots are sensitive to drought and that their live/dead ratios are decreasing with less water availability in the soil [54-57]. In water-saturated forest ecosystems the primary production of fine roots may exceed the decomposition of dead roots, also leading to a decreased live/dead ratio $[32,58,59]$. In many cases death takes place as a result of ageing, reduced carbohydrate supply, the influence of different climatic stress factors such temperature changes and frost $[49,60]$. Increased fine-root herbivory especially in nutrient-rich patches is furthermore expected to significantly influence the carbon cycling patterns [61].

Although our sampling occasions were few, our data from the coniferous fern site at Forsmark suggest that substantial increases/decreases in live, dead, and live + dead fine roots will take place during the growth period (Table 3 ). The annual above-ground litter fall (mainly Picea abies needles) was $135 \mathrm{~g} \mathrm{~m}^{2}$ compared with the annual below-ground fine-root litter supply of $257 \mathrm{~g} \mathrm{~m}^{2}$ [62] (Table 3). Our study suggests that the annual above-ground tree litter fall from leaves/needles is less important in terms of dry weight than the annual belowground formation of fine-root litter.

Available information in the literature suggests a fineroot production with a seasonal pattern different from needle or leaf production $[26,63,64]$. Fine roots respond quickly to environmental changes and their life span is relatively short. Our investigation confirms that the growth pattern of the fine roots depends on where in the soil profile they are developed and that the live/dead ratio is decreasing with depth (Table 2).

"Vitality" in terms of live/dead ratios of fine roots should be expected to be high in the humus layer, since the extensive mycorrhizal infection in that layer makes the fine roots functional over a prolonged period of time [6568]. Although no distinct seasonal pattern is reported in the literature a high growth and death rate of fine roots should be expected during the summer months $[8,69]$. A high death rate was observed during the winter month and early spring (Table 3). Dead fine roots are decomposed quickly in welloxidized soil layers ensuring a high live/dead ratio of fine roots. 
Detritus from above-ground and below-ground plant tissues constitutes the primary source of carbon for soil organic matter [28]. The presence of soil organic matter improves the nutrient availability and reduces soil strength. Tree fine roots may play a more important role for the formation of soil organic matter than the needles/leaves [8, 22, 26, 70-73]. In strongly seasonal climates, the length of the growing season often increases the lifespan of needles/leaves, but fine roots may stay alive less long.

Sequential coring data at the ecosystem scale suggest an annual production of fine roots, frequently higher than the average amount of live fine-roots $[8,17,22,26,74-78]$. Most observations on fine-root turnover are underestimates and the costs and benefits of exudation, root hairs and the mycorrhizal fungi is not yet sufficiently clarified [43]. Techniques for obtaining root data are still in a formative stage. As more research is conducted on root methods, techniques will become more refined and standardized. Obtaining root data is essential for all kind of long-term field experiments, because plant responses may occur in the shifts in carbon allocation between above- and below-ground plant components.

Decomposition of fine roots is determined mainly by the interactions between soil temperature and oxygen accessibility [79]. Other factors regulating the fate of dead fine roots in the soil are the soil $\mathrm{pH}$, the availability of decomposer organisms, and litter quality $[22,80,81]$. Only few studies have considered the interactions between all these factors [32, $33,35,52,53,71,79,82-84]$. Estimates of root respiration to the total $\mathrm{CO}_{2}$ efflux range from $10 \%$ to $90 \%$, with considerable methodological uncertainties $[35,84]$.

The high amount of dead fine roots accumulated in our two anoxic forest sites unveils a high turnover rate of live fine roots. The changes between anoxic and well-oxidized soil conditions in a forest soil may cause death of both fine roots and mycorrhiza $[33,52]$. The effects of anoxia on the metabolic cost on the plant root system and the mycorrhizal infection have so far received limited attention $[32,59,85]$. Uncertainties in the belowground carbon balances limit the establishment and improvement of policies regulating the atmospheric $\mathrm{CO}_{2}$ concentrations.

Trees constitute major reservoirs of carbon in terrestrial ecosystems; large amounts of carbohydrates are annually transported from the shoots to the roots and stored in the root systems $[4,5,9,11,13,21,25,48,64,72]$. High amounts of live and dead fine roots are found in forest ecosystems $[8,12,15,55,80]$. The vitality of the fine roots seem to depend on where in the soil profile they are developed; it is therefore essential, while studying the distribution of fine roots in forest ecosystems, to relate to the natural soilhorizons $[15,46]$. The often well-developed organic-rich humus layer in the forest soil most effectively buffers the root system against drought and nutrient deficiencies [15, 69]. Few studies have so far examined patterns in live/dead ratios of fine roots in relation to soil water and mineral nutrient availability during the growth period $[15,24,74]$. Fine roots of trees in many ways are indicators of environmental change, soil nutrient status, and forest health [14, 16, 47].

\section{Acknowledgments}

The author is grateful for financial support from the Swedish Nuclear Fuel and Waste Management Co. (SKB).

\section{References}

[1] L. Kutschera, E. Lichtenegger, M. Sobotik, and D. Haas, "Wurzeln. Bewurzelung von Pflanzen in verschiedenen Lebensräumen. 5. Band der Wurzelatlas-Reihe," Stapfia, vol. 49, p. 331, 1997.

[2] H. Persson, "Fine-root production, mortality and decomposition in forest ecosystems," Vegetatio, vol. 41, no. 2, pp. 101109, 1980.

[3] T. Persson, "Structure and function of northern coniferous forests," Ecological Bulletin, vol. 32, pp. 1-609, 1979.

[4] H. Persson, "Root system in arboreal plants," in Plant Rootsthe Hidden Half, Y. Waisel, A. Eshel, and U. Kafksfi, Eds., pp. 187-204, 3rd edition, 2002.

[5] M. M. Caldwell, "Root structure: the considerable cost of belowground function," in Topics in Plant Population Biology, O. T. Solbrig, S. Jain, G. B. Johnson, and P. H. Raven, Eds., pp. 408-427, Columbia University Press, New York, NY, USA, 1979.

[6] P. Jensén and S. Pettersson, "Nutrient uptake in roots of Scots pine," Ecological Bulletin, vol. 32, pp. 229-237, 1977.

[7] A. H. Fitter, "Magnolioid roots-hairs, architecture and mycorrhizal dependency," New Phytologist, vol. 164, no. 1, pp. 1516, 2004.

[8] H. Persson, "Root dynamics in a young Scots pine stand in Central Sweden," Oikos, vol. 30, pp. 508-519, 1978.

[9] G. Ågren, B. Axelsson, J. G. K. Flower-Ellis et al., "Annual carbon budget for a young Scots pine," Ecological Bulletins, vol. 32, pp. 307-313, 1980.

[10] R. Fogel, "Root turnover and productivity of coniferous forests," Plant and Soil, vol. 71, no. 1-3, pp. 75-85, 1983.

[11] R. B. Jackson, J. Canadell, J. R. Ehleringer, H. A. Mooney, O. E. Sala, and E. D. Schulze, "A global analysis of root distributions for terrestrial biomes," Oecologia, vol. 108, no. 3, pp. 389-411, 1996.

[12] I. A. Janssens, D. A. Sampson, J. Curiel-Yuste, A. Carrara, and R. Ceulemans, "The carbon cost of fine root turnover in a Scots pine forest," Forest Ecology and Management, vol. 168, no. 1-3, pp. 231-240, 2002.

[13] K. A. Vogt, D. J. Vogt, and J. Bloomfield, "Input of organic matter to the soil by tree roots," in Plant Roots and Their Environment, B. L. McMichael and H. Persson, Eds., pp. 171-190, Elsevier Science, Amsterdam, The Netherlands, 1991.

[14] L. Finér, H.-S. Helmisaari, K. Lõhmus et al., "Variation in fine root biomass of three European tree species: beech (Fagus sylvatica L.), Norway spruce (Picea abies L. Karst.), and Scots pine (Pinus sylvestris L.)," Plant Biosystems, vol. 141, no. 3, pp. 394-405, 2007.

[15] H. Persson and I. Stadenberg, "Fine root dynamics in a Norway spruce forest (Picea abies (L.) Karst) in eastern Sweden," Plant and Soil, vol. 330, no. 1, pp. 329-344, 2010.

[16] H. S. Helmisaari, K. Makkonen, S. Kellomäki, E. Valtonen, and E. Mälkönen, "Below- and above-ground biomass, production and nitrogen use in Scots pine stands in eastern Finland," Forest Ecology and Management, vol. 165, no. 1-3, pp. 317326, 2002.

[17] I. Ostonen, K. Lõhmus, and R. Lasn, "The role of soil conditions in fine root ecomorphology in Norway spruce (Picea 
abies (L.) Karst.)," Plant and Soil, vol. 208, no. 2, pp. 283-292, 1999.

[18] A. Ericsson and H. Persson, "Seasonal changes in starch reserves and growth of fine roots of 20-year old Scots pines," Ecological Bulletin, vol. 32, pp. 239-250, 1980.

[19] M. R. Bakker, Effect des amendements calciques sur les racines fines de chêne (Quercus petrea et robur): conséquences des changements dans la rhizosphère, Doctoral thesis, I'Université Henri Poincaré, Nancy, France, 1998.

[20] M. R. Bakker, J. Garbaye, and C. Nys, "Effect of liming on the ectomycorrhizal status of oak," Forest Ecology and Management, vol. 126, no. 2, pp. 121-131, 2000.

[21] R. J. Norby, J. Ledford, C. D. Reilly, N. E. Miller, and E. G. O'Neill, "Fine-root production dominates response of a deciduous forest to atmospheric $\mathrm{CO}_{2}$ enrichment," Proceedings of the National Academy of Sciences of the United States of America, vol. 101, no. 26, pp. 9689-9693, 2004.

[22] H. Helmisaari and H.-S. Helmisaari, Long-Term Forest Fertilization Experiments in Finland and Sweden, Swedish Environmental Protection Agency, 1992.

[23] H. S. Helmisaari and L. Hallbäcken, "Fine-root biomass and necromass in limed and fertilized Norway spruce (Picea abies (L.) Karst.) stands," Forest Ecology and Management, vol. 119, no. 1-3, pp. 99-110, 1999.

[24] C. Stober, G. A. Eckart, and H. Persson, "Root growth and response to nitrogen," in Carbon and Nitrogen Cycling in European Forest Ecosystems, Ecological Studies, E. D. Schulze, Ed., vol. 142, pp. 99-121, Springer, Berlin, Germany, 2000.

[25] K. A. Vogt, C. C. Grier, and D. J. Vogt, "Production, turnover and nutrient dynamics of above- and below-ground detritus of world forest," Advances in Ecological Research, vol. 15, pp. 303-377, 1986.

[26] H. Persson and I. Stadenberg, "Spatial distribution of fineroots in boreal forests in eastern Sweden," Plant and Soil, vol. 318, no. 1-2, pp. 1-14, 2009.

[27] H. Persson and K. Ahlström, "Fine-root response to nitrogen supply in nitrogen manipulated Norway spruce catchment areas," Forest Ecology and Management, vol. 168, no. 1-3, pp. 29-41, 2002.

[28] S. Fontaine, A. Mariotti, and L. Abbadie, "The priming effect of organic matter: a question of microbial competition?" Soil Biology and Biochemistry, vol. 35, no. 6, pp. 837-843, 2003.

[29] S. Fontaine, G. Bardoux, L. Abbadie, and A. Mariotti, "Carbon input to soil may decrease soil carbon content," Ecology Letters, vol. 7, no. 4, pp. 314-320, 2004.

[30] A. Löfgren, S. Miliander, J. Truvé, and T. Lindborg, "Carbon budgets for catchments across a managed landscape mosaic in southeast Sweden: contributing to the safety assessment of a nuclear waste repository," Ambio, vol. 35, no. 8, pp. 459-468, 2006.

[31] M. R. Bakker, L. Augusto, and D. L. Achat, "Fine root distribution of trees and understory in mature stands of maritime pine (Pinus pinaster) on dry and humid sites," Plant and Soil, vol. 286, no. 1-2, pp. 37-51, 2006.

[32] A. J. Cantelmo Jr. and J. G. Ehrenfeld, "Effects of microtopography on mycorrhizal infection in Atlantic white cedar (Chamaecyparis thyoides (L.) Mills.)," Mycorrhiza, vol. 8, no. 4, pp. 175-180, 1999.

[33] R. H. Jones, B. G. Lockaby, and G. L. Somers, "Effects of microtopography and disturbance on fine-root dynamics in wetland forests of low-order stream floodplains," American Midland Naturalist, vol. 136, no. 1, pp. 57-71, 1996.

[34] Y. Abernethy and R. E. Turner, "US Forested Wetlands: 1940 1980. Field-data surveys document changes and can guide national resource management," BioScience, vol. 37, pp. 721727, 1987.

[35] G. Rapalee, S. E. Trumbore, E. A. Davidson, J. W. Harden, and H. Veldhuis, "Soil carbon stocks and their rates of accumulation and loss in a boreal forest landscape," Global Biogeochemical Cycles, vol. 12, no. 4, pp. 687-701, 1998.

[36] H. Sjörs, "Amphi-atlantic zonation, nemoral to arctic," in North Atlantic Biota and Their History, A. Löve and D. Löve, Eds., pp. 109-125, Pergamon Press, Oxford, UK, 1963.

[37] S. C. Chang and E. Matzner, "Soil nitrogen turnover in proximal and distal stem areas of European beech trees," Plant and Soil, vol. 218, no. 1-2, pp. 117-125, 2000.

[38] G. L. Tierney, T. J. Fahey, P. M. Groffman et al., "Environmental control of fine root dynamics in a northern hardwood forest," Global Change Biology, vol. 9, no. 5, pp. 670-679, 2003.

[39] Anon. Nordiska Ministerrådet. Vegetationstyper. Representativa naturtyper och hotade biotoper I Norden. Remissupplaga, 1978.

[40] L. Lundin, E. Lode, J. Stendahl, P.-A. Melkerud, L. Björkvall, and A. Thorstensson, "Soil and site types in the Forsmark area," SKB R-04-08, Sv. Kärnbränslehantering AB, 2004.

[41] L. Lundin, E. Lode, J. Stendahl, L. Björkvall, and J. Hansson, "Soil and site types in the Oskarshamn area," SKB R-05-15, Sv. Kärnbränslehantering AB, 2005.

[42] A. Clemensson-Lindell and H. Persson, "Effects of freezing on rhizosphere and root nutrient content using two soil sampling methods," Plant and Soil, vol. 139, no. 1, pp. 39-45, 1992.

[43] K. A. Vogt and H. Persson, "Measuring growth and development of roots," in Techniques and Approaches in Forest Tree Ecophysiology, J. P. Lassoie and T. M. Hinckley, Eds., pp. 477501, CRC Press, 1991.

[44] R. Agerer, Ed., Colour Atlas of Ectomycorrhizae, Eduard Dietenberger Gmbh, München, Germany, 1987-1993.

[45] L. H. Comas, D. M. Eissenstat, and A. N. Lakso, "Assessing root death and root system dynamics in a study of grape canopy pruning," New Phytologist, vol. 147, no. 1, pp. 171-178, 2000.

[46] W. Borken, G. Kossmann, and E. Matzner, "Biomass, morphology and nutrient contents of fine roots in four Norway spruce stands," Plant and Soil, vol. 292, no. 1-2, pp. 79-93, 2007.

[47] H. S. Helmisaari, J. Derome, P. Nöjd, and M. Kukkola, "Fine root biomass in relation to site and stand characteristics in Norway spruce and Scots pine stands," Tree Physiology, vol. 27, no. 10, pp. 1493-1504, 2007.

[48] J. W. Raich and K. J. Nadelhoffer, "Belowground carbon allocation in forest ecosystems: global trends," Ecology, vol. 70, no. 5, pp. 1346-1354, 1989.

[49] E. R. C. Reynolds, "Root distribution and the cause of its spatial variability in Pseudotsuga taxifolia (Poir.) Britt," Plant and Soil, vol. 32, no. 1, pp. 501-517, 1970.

[50] H. J. van Praag, S. Sougnez-Remy, F. Weissen, and G. Carletti, "Root turnover in a beech and a spruce stand of the Belgian Ardennes," Plant and Soil, vol. 105, no. 1, pp. 87-103, 1988.

[51] W. H. Lyford, "Rhizography of non-woody roots of trees in forest floor," in The Development and Function of Roots, J. G. Torrey and D. T. Clarkson, Eds., pp. 179-196, Academic Press, London, UK, 1975.

[52] F. P. Day, J. P. Megonigal, and L. C. Lee, "Cypress root decomposition in experimental wetland mesocosms," Wetlands, vol. 9, no. 2, pp. 263-282, 1989.

[53] V. J. Lieffers and R. L. Rothwell, "Rooting of peatland black spruce and tamarack in relation to depth of water table," Canadian Journal of Botany, vol. 65, no. 5, pp. 817-821, 1987. 
[54] A. F. M. Olsthoorn, "Fine root density and root biomass of two Douglas-fir stands on sandy soils in the Netherlands. 1. Root biomass in early summer," Netherlands Journal of Agricultural Science, vol. 39, no. 1, pp. 49-60, 1991.

[55] H. Persson, H. Majdi, and A. Clemensson-Lindell, "Effects of acid deposition on tree roots," Effects of Acid Deposition and Tropospheric Ozone on Forest Ecosystems in Sweden, pp. 158167, 1995.

[56] J. Puhe, H. Persson, and I. Börjesson, "Wurzelwachtum und wurzelshäden in skandinavischen nadelwäldern,” $A F Z$, vol. 20, pp. 488-492, 1986.

[57] D. Santantonio and R. K. Hermann, "Standing crop, production, and turnover of fine roots on dry, moderate, and wet sites of mature Douglas-fir in western Oregon," Annals of Forest Science, vol. 42, pp. 113-142, 1985.

[58] D. Santantonio, R. K. Hermann, and W. S. Overton, "Root biomass studies in forest ecosystems," Pedobiologia, vol. 17, pp. $1-31,1977$.

[59] B. A. D. Hetrick, "Mycorrhizas and root architecture," Cellular and Molecular Life Sciences, vol. 47, pp. 355-362, 2005.

[60] J. D. Marshall and R. H. Waring, "Predicting fine root production and turnover by monitoring root starch and soil temperature," Canadian Journal of Forest Research, vol. 15, no. 5, pp. 791-800, 1985.

[61] G. N. Stevens and R. H. Jones, "Patterns in soil fertility and root herbivory interact to influence fine-root dynamics," Ecology, vol. 87, no. 3, pp. 616-624, 2006.

[62] K. Mjöfors, M.-B. Johansson, Å. Nilsson, and R. Hyvönen, "Input and turnover of forest tree litter in the Forsmark and Oskarshamn areas," SKB R-07-23, Sv Kärnbränslehantering $\mathrm{AB}, 2007$.

[63] K. Makkonen and H. S. Helmisaari, "Assessing fine-root biomass and production in a Scots pine stand-comparison of soil core and root ingrowth core methods," Plant and Soil, vol. 210, no. 1, pp. 43-50, 1999.

[64] H. Persson, "The distribution and productivity of fine roots in boreal forests," Plant and Soil, vol. 71, no. 1-3, pp. 87-101, 1983.

[65] M. C. Brundrett, "Coevolution of roots and mycorrhizas of land plants," New Phytologist, vol. 154, no. 2, pp. 275-304, 2002.

[66] D. M. Durall, J. D. Marshall, M. D. Jones, R. Crawford, and J. M. Trappe, "Morphological changes and photosynthate allocation in ageing Hebeloma crustuliniforme (Bull.) Quel. and Laccaria bicolor (Maire) Orton mycorrhizas of Pinus ponderosa Dougl. ex Laws," New Phytologist, vol. 127, no. 4, pp. 719-724, 1994.

[67] J. E. Hooker, K. E. Black, R. L. Perry, and D. Atkinson, "Arbuscular mycorrhizal fungi induced alteration to root longevity of poplar," Plant and Soil, vol. 172, no. 2, pp. 327-329, 1995.

[68] H. Marschner, Mineral Nutrition of Higher Plants, Academic Press, 2nd edition, 2002.

[69] D. Gaul, D. Hertel, W. Borken, E. Matzner, and C. Leuschner, "Effects of experimental drought on the fine root system of mature Norway spruce," Forest Ecology and Management, vol. 256, no. 5, pp. 1151-1159, 2008.

[70] R. W. Ruess, K. Van Cleve, J. Yarie, and L. A. Viereck, "Contributions of fine root production and turnover to the carbon and nitrogen cycling in taiga forests of the alaskan interior," Canadian Journal of Forest Research, vol. 26, no. 8, pp. 1326-1336, 1996.

[71] R. A. Scheffer and R. Aerts, "Root decomposition and soil nutrient and carbon cycling in two temperate fen ecosystems," Oikos, vol. 91, no. 3, pp. 541-549, 2000.
[72] G. Scarascia-Mugnozza, G. A. Bauer, H. Persson, G. Matteucci, and A. Masci, "Tree biomass, growth and nutrient pools," in Carbon and Nitrogen Cycling in European Forest Ecosystems. Ecological Studies, E. D. Schulze, Ed., vol. 142, pp. 49-62, Springer, Berlin, Germany, 2000.

[73] P. Vanninen and A. Mäkelä, "Fine root biomass of scots pine stands differing in age and soil fertility in southern Finland," Tree Physiology, vol. 19, no. 12, pp. 823-830, 1999.

[74] B. John, H. N. Pandey, and R. S. Tripathi, "Vertical distribution and seasonal changes of fine and coarse root mass in Pinus kesiya royle ex.Gordon forest of three different ages," Acta Oecologica, vol. 22, no. 5-6, pp. 293-300, 2001.

[75] Y. Son and J. H. Hwang, "Fine root biomass, production and turnover in a fertilized Larix leptolepis plantation in central Korea," Ecological Research, vol. 18, no. 3, pp. 339-346, 2003.

[76] S. Usman, S. P. Singh, and Y. S. Rawat, "Fine root productivity and turnover in two evergreen central Himalayan forests," Annals of Botany, vol. 84, no. 1, pp. 87-94, 1999.

[77] Y. S. Yang, G. S. Chen, P. Lin, J. S. Xie, and J. F. Guo, "Fine root distribution, seasonal pattern and production in four plantations compared with a natural forest in Subtropical China," Annals of Forest Science, vol. 61, no. 7, pp. 617-627, 2004.

[78] S. Zewdie, M. Fetene, and M. Olsson, "Fine root vertical distribution and temporal dynamics in mature stands of two enset (Enset ventricosum Welw Cheesman) clones," Plant and Soil, vol. 305, no. 1-2, pp. 227-236, 2008.

[79] E. A. Davidson, E. Belk, and R. D. Boone, "Soil water content and temperature as independent or confounded factors controlling soil respiration in a temperate mixed hardwood forest," Global Change Biology, vol. 4, no. 2, pp. 217-227, 1998.

[80] D. L. Godbold, H. W. Fritz, G. Jentschke, H. Meesenburg, and P. Rademacher, "Root turnover and root necromass accumulation of Norway spruce (Picea abies) are affected by soil acidity," Tree Physiology, vol. 23, no. 13, pp. 915-921, 2003.

[81] H. Eijsackers and A. J. B. Zehnder, "Litter decomposition: a Russian matriochka doll," Biogeochemistry, vol. 11, no. 3, pp. 153-174, 1990.

[82] R. D. Newsom, T. T. Kozlowski, and Z. C. Tang, "Responses of Ulmus americana seedlings to flooding of soil," Canadian Journal of Botany, vol. 60, no. 9, pp. 1688-1695, 1982.

[83] E. J. Sayer, E. V. J. Tanner, and A. W. Cheesman, "Increased litterfall changes fine root distribution in a moist tropical forest," Plant and Soil, vol. 281, no. 1-2, pp. 5-13, 2006.

[84] R. J. Norby and R. B. Jackson, "Root dynamics and global change: seeking an ecosystem perspective," New Phytologist, vol. 147, no. 1, pp. 3-12, 2000.

[85] D. L. Godbold, M. R. Hoosbeek, M. Lukac et al., "Mycorrhizal hyphal turnover as a dominant process for carbon input into soil organic matter," Plant and Soil, vol. 281, no. 1-2, pp. 15$24,2006$. 

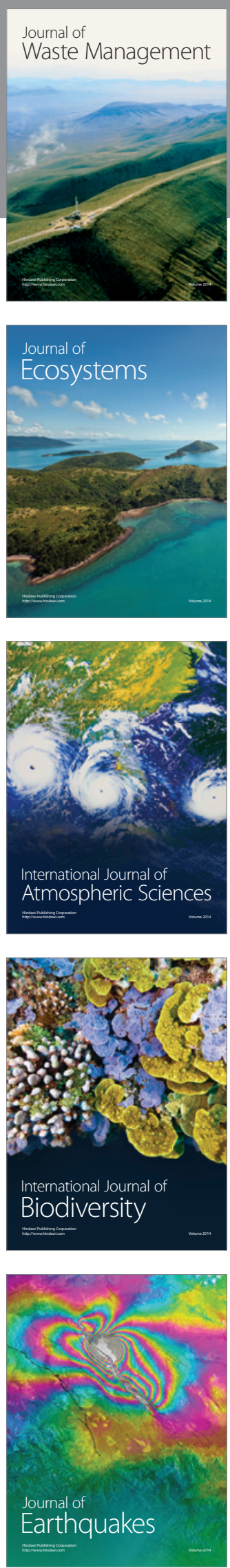
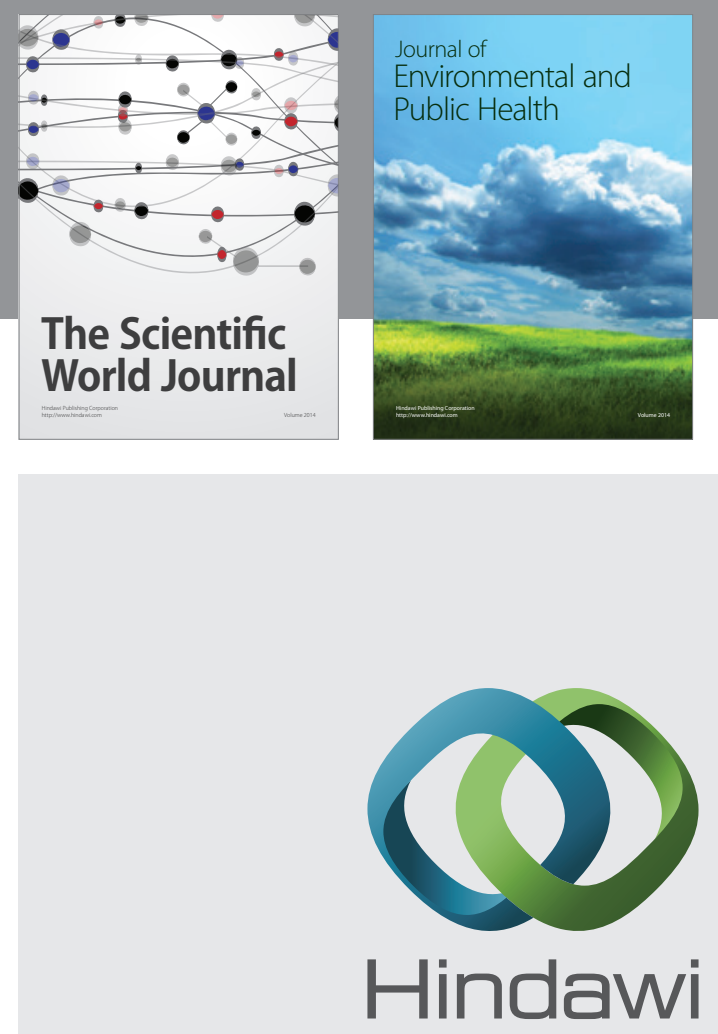

Submit your manuscripts at

http://www.hindawi.com
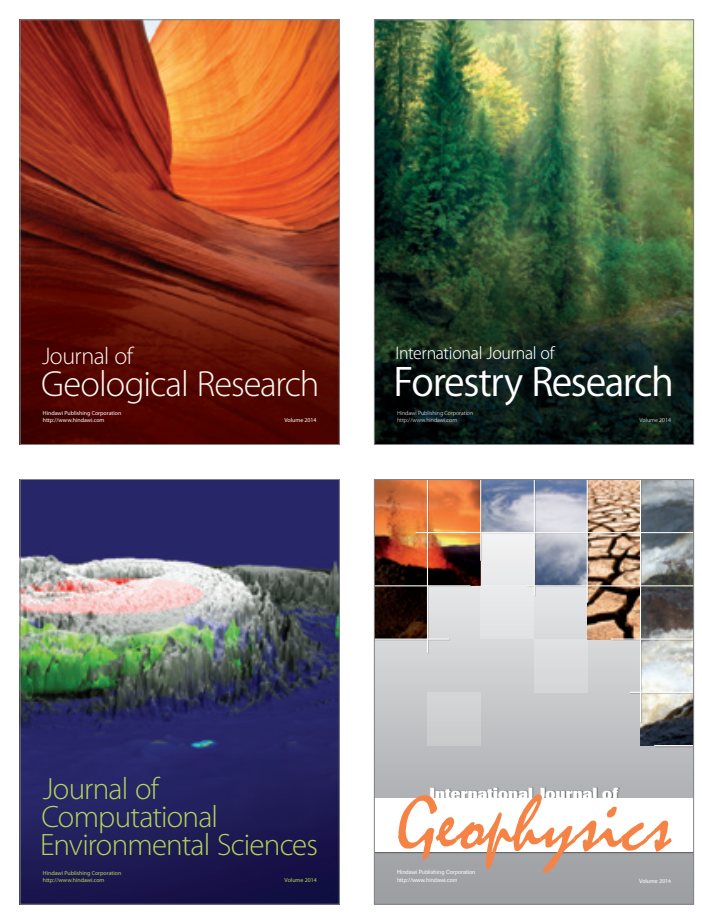
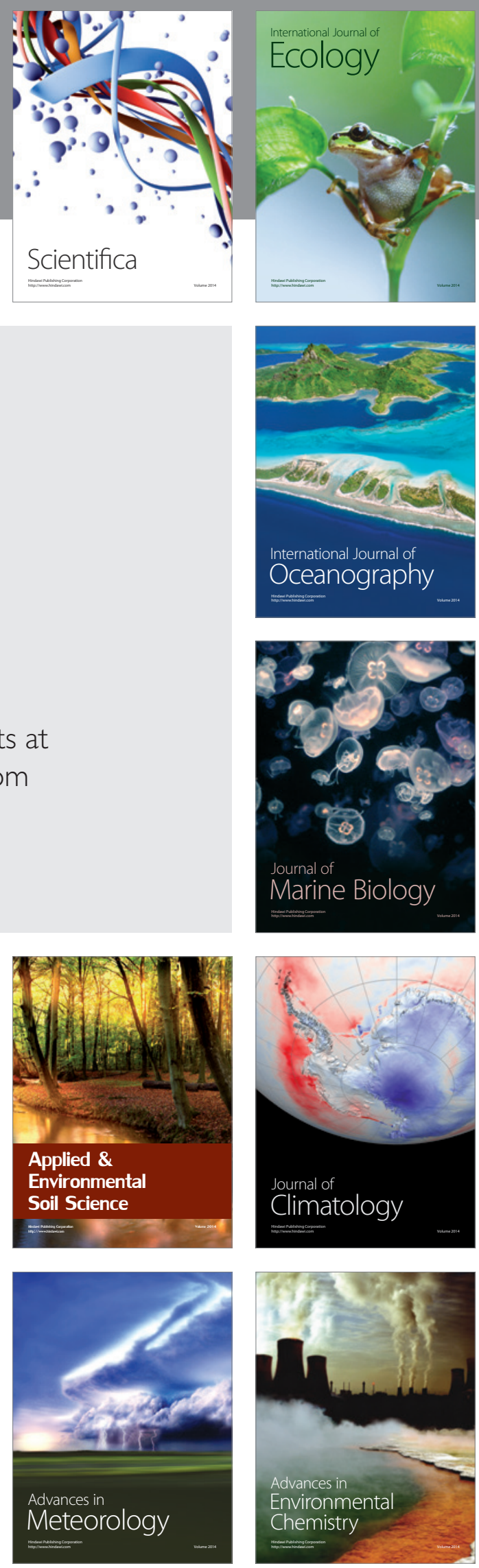